\title{
Nego Fugido
}

Runaway Nigger

Negro Fugitivo

João Vicente Annoni Albuquerque ${ }^{1}$
Maria Betânia e Silva

1 Graduado em Artes Visuais pela Universidade Federal de Pernambuco. Atuou na Galeria de Arte Janete Costa, em Recife. Atuou na TV Pinguim, em São Paulo. Fez mobilidade acadêmica na UFMG. É Artista Visual e Tatuador.

2 Doutora em Educação pela UFMG. Mestre em Educação pela UFPE. Graduada em Artes Plásticas pela UFPE. Graduanda em Filosofia pela UFPE. Professora da Graduação em Artes Visuais e do Programa de Pós-graduação em Artes Visuais UFPE/UFPB. 


\section{Resumo}

Esse texto investiga a manifestação cultural popular do Nego Fugido, suas relações com a história do Brasil e de que maneira afeta a comunidade pesqueira de Acupe, estado da Bahia, local onde é realizado o evento. Apresentamos uma descrição do evento, seus elementos simbólicos, como se destacam nas indumentárias das personagens, os processos que envolvem esse movimento na narrativa em si e que se mesclam nos causos e relatos dos moradores. A partir da experiência vivenciada no evento, foram realizados registros e esboços em desenho, durante e após a apresentação que se desmembraram em produções artísticas que refletem a expressividade do evento. São tecidas reflexões acerca dos conceitos de identidade e tradição que permeiam o movimento, assim como os fatores de vigilância e relações de poder presentes nos personagens. Aponta o papel da memória nas experiências vivenciadas que se tornam significativas ao longo da vida, servindo de molas propulsoras para o processo criativo no campo das Artes Visuais.

\section{Palavras-chave}

Nego Fugido; Manifestação cultural popular; Memórias; Processo criativo; Artes Visuais.

\section{Abstract}

This text investigates the popular cultural manifestation of Nego Fugido, its relations with the history of Brazil and how it affects the fishing community of Acupe, state of Bahia, where the event is being held. We present a description of the event, they're symbolic elements, as they stand out in the character's costumes, the processes that involve this movement movement in the narrative itself and that are mixed in the stories and legends of the residents. From experience lived in the event, records and sketches in drawing were made, during and after the presentation which split into artistc prodution that reflect the expressiveness of the event. The research generates a reflection on the concepts of identity and tradition that permeate the movement, as well as the factors of vigilance and power relations present in each represented character. Furthermore, it highlights the important role of memory in the lived experiences that become significant throughout life, serving as propelling springs for the creative process in the field of Visual Arts.

\section{Key words}

Nego Fugido; Popular cultural manifestation; Memories; Creative process, Visual Arts.

\section{Resumen}

Este texto investiga la manifestación cultural popular de Nego Fugido, sus relaciones con la historia de Brasil y cómo afecta a la comunidad pesquera de Acupe, estado de Bahia, donde se realiza el evento. Presentamos una descripción del evento, sus elementos simbólicos, como se destacan en el vestuario del personaje, los procesos que involucran este movimiento en la propria narrativa y que se mesclan en las historias y leyendas de los vecinos. A partir de la experiencia vivida en el evento, se realizaran registros y dibujos, durante y después de la presentación, que se dividieran en producciones artísticas que reflejan la expresividad del evento. La investigación genera una reflexión sobre los conceptos de identidad y tradición que permean el movimiento, así como los factores de vigilancia y relaciones poder presentes en cada personaje representado. Además, destaca el importante papel de la memoria en las experiencias vividas que se vuelven significativas a lo largo de la vida, sirviendo como resortes impulsores del proceso creativo en el campo de las Artes Visuales.

\section{Palabras-Clave}

Nego Fugido; Manifestación cultural popular; Recuerdos; Proceso Creativo; Artes Visuales.

\section{ISSN: 2447-1267}




\section{Introdução}

A festa do Nego Fugido realizada na comunidade Quilombola de Acupe, localizada no município de Santo Amaro da Purificação no Recôncavo Baiano existe há gerações. Uma tradição que mobiliza e envolve todos os moradores do local há décadas. Existe uma carga histórica por trás desse evento, uma narrativa que ilustra os conflitos e as relações de poder do período colonial no Brasil.

Registrar esse evento histórico cultural pode ser feito de diversas maneiras atualmente. Inclusive a notoriedade do Nego Fugido vem crescendo nas mídias digitais, no Instagram, por exemplo, já existe a Hashtag: \#negofugidoacupe. Fotos e vídeos nos dão uma clara percepção da estética do evento. Mas, e no campo da Arte? É possível produzir artisticamente uma narrativa para o/a leitor/a adentrar profundamente no contexto? Captando os aspectos históricos e sociais?

A partir desse processo investigativo, a criação artística visou, não somente servir como veículo comunicativo, mas educativo também, de maneira a enriquecer a leitura com imagens. No intuito de produzir imageticamente uma estória, a imagem mescla linguagem visual à leitura, permitindo um horizonte de possibilidades didáticas para se veicular um conteúdo de tamanha importância política e histórica ao processo criativo a partir da experiência vivida no evento. É o exercício de reaver uma memória sobre uma experiência que foi compartilhada e registrada durante e depois do evento. Imagens criadas com lápis, tinta e pincéis que estão retratando fatos históricos (não objetivos) transmitidos pela oralidade da comunidade que ali viveu e vive e que tem seu lado lúdico, atrelado a fortes revoltas do século XIX.

A configuração da festa é passada de geração em geração. Não necessariamente há uma narrativa única que define como de fato aconteceram as resistências do povo negro durante o período escravocrata. Mas, o objeto artístico e educativo que complementa e reitera essa pesquisa tem como objetivo enaltecer a riqueza da ação em si. Não somente como um movimento artístico de cunho carnavalesco e grotesco até, mas principalmente político, em reafirmar as lutas sociais do passado que permitem leituras desse presente. Cada personagem e elemento existente nesse teatro de rua que envolve os mais diversos simbolismos e traz consigo um retrato das relações de poder da época, são figuras marcadas por sua posição social, que se destacam de maneira abrupta no decorrer das cenas. É preciso frisar aqui, que apresentamos uma parte dessa produção.

Não encontramos, de fato, uma nomenclatura única para o movimento do Nego Fugido, por se tratar de uma manifestação cultural popular, secular, um teatro de rua que traz críticas sociais, políticas e históricas. Nessa breve "definição" observa-se o leque de conceitos que se abrem.

O estudo se vale da perspectiva metodológica artográfica (DIAS; IRWIN, 2013) que envolve a educação enquanto instrumento de conscientização acerca do movimento Nego Fugido, a produção artística no próprio fazer da pesquisa e o ato do pesquisar que inclui o aprofundamento também de fatores político-histórico- 
sociais. A produção imagética está vinculada diretamente às memórias pessoais da experiência vivida.

Outro elemento importante a ser discutido é o local de fala onde buscamos formas de compreender o quão impactante foi se deparar com encenações violentas que representam a história do nosso país durante a escravidão, a mesma não se encontra de forma tão visceral nos livros de história escolar. $O$ racismo estrutural e social presente no Brasil é uma sequela de mais de 400 anos de escravidão que ainda se perpetua em diversas situações, seja em relações de trabalho ou sociais. É intrínseco em qualquer brasileiro, ainda mais nos brancos. Basta vermos a extensa produção acadêmica acerca do racismo, escrita na maioria das vezes por homens brancos europeus ou descendentes. Se tratando do conceito de branquitude, que vem sendo trabalhado por diversos teóricos ao longo das décadas partindo do século $X X$, só vem ganhando destaque no âmbito acadêmico.

O trabalho do pesquisador Lourenço Cardoso (2010) estabelece uma diferenciação que se aproxima do conceito sugerido por Edith Piza. Cardoso desenvolve duas categorias para situar a branquitude no quadro social: branquitude crítica e branquitude acrítica. Segundo ele, "a branquitude crítica refere-se ao indivíduo que desaprova publicamente o racismo". Já branquitude acrítica refere-se ao indivíduo ou coletividade que luta pela manutenção do status de superioridade racial branca. "Apesar do apoio as práticas racistas ou da inação diante delas, a branquitude acrítica pode não se considerar racista porque, segundo sua concepção, a superioridade racial branca seria uma realidade inquestionável" (CARDOSO, 2010, p. 63). Segundo Cardoso, uma das razões para distinguir a branquitude em crítica e acrítica, se sustenta pelo fato de que os principais estudiosos estabelecem uma diferenciação ao tratar as diversas formas de racismos, mas ao definir a branquitude o fazem de maneira genérica o que não é suficiente para compreender como se configura o conflito racial que tem se perpetuado. "Ao observar o grupo branco de longe, de repente, pode surgir a impressão de que a branquitude é homogênea, porém, com a aproximação percebese o quanto os brancos são diversos" (Ibidem). Dito isto, o autor atesta a necessidade de se pensar a branquitude nos seus aspectos mais específicos e mutáveis (JESUS, 2012, p. 9).

Essa pesquisa se trata de uma branquitude crítica, que como dito na citação procuramos rever seus privilégios de cor e classe, e a partir deles trazer reflexões que contribuam para a luta antiracista, buscando de fato uma igualdade racial.

O trecho retirado do artigo de Camila Moreira de Jesus, publicado no III Encontro Baiano de Estudos em Cultura, traz esse debate à tona, nas diferenciações além da nomenclatura entre branquidade e branquitude.

Aproximar o/a leitor/a do movimento sob a perspectiva imagética, aqui apresentada, objetiva suscitar uma compreensão acerca dos sentimentos ali vividos, apontando a importância em resgatar a memória ancestral do povo negro. Assim, na primeira parte do texto apresentamos um pouco do contexto histórico do Nego Fugido trazendo elementos da comunidade e do evento. Na segunda parte, o 
foco está centrado em analisar os conceitos que permeiam a encenação, tais como identidade, tradição e vigilância. Por fim, a produção artística constitui e entrelaça toda a narrativa.

\section{Nego Fugido e sua história}

Acupe significa terra quente em Tupi, juntamente com o nome do rio Açu que atravessa a vila gera a frase "Terra quente ao pé do rio Açu". Um lugar formado por pescadores e marisqueiros desde a época da escravidão, onde muitos escravos conseguiam comprar bens e até alforrias através da pesca.

A região do recôncavo baiano foi marcada por diversas revoltas nos períodos de 1810 a 1830 especificamente. Diante da diáspora do povo negro e a imposição de uma cultura colonizadora, os residentes de Acupe trazem à tona uma memória oral a respeito de sua história. Tendo em vista que a história do Brasil, como conhecemos, tem uma ótica do ponto de vista do colonizador e opressor, onde não há uma busca fiel sobre o que foram os levantes e as revoltas que ocorreram no passado.

Há muitos casos que permeiam a história da comunidade, envolvendo misticismo e figuras da colônia. Em sua dissertação de mestrado, Pinto (2014) descreve um desses relatos:

Para compreender de fato o contexto em que está inserido as aparições das manifestações populares da cultura de Acupe, nas tardes dos domingos de julho, é importante observar os aspectos místicos, simbólicos e estranhos/ exóticos presentes na comunidade. Paulo Henrique da Cruz, um jovem tata da casa de nação angola, Inzo Tumbalê Junçara, em Acupe, por exemplo, contou-me uma versão curiosa sobre a presença das manifestações de julho nas ruas: para ele, essas aparições começaram com os mandus. Os escravos do Engenho Acupe que eram de nação haussás, segundo sua narrativa, faziam muitos cultos a mando do senhor de engenho, oferecendo até mesmo pessoas em sacrifício, para adquirir bens e dinheiro. Os escravos teriam perdido o controle da situação, pois faziam muitas macumbas e, não tendo mais pessoas para oferecer, teriam parado as oferendas. Iku, a morte, teria ficado furioso e lançado uma praga no mês de agosto. Desde então, sempre nesse mês, passaram a morrer muitas pessoas da comunidade. Todos temiam a chegada do mês das tragédias. Os sacerdotes da época, diz o tata, teriam se juntado e feito uma oferenda para afastar a praga de Acupe. Os mandus, espíritos bons, saíram às ruas em julho, um mês antes, para afastar os espíritos maus e atrair os bons, livrando a comunidade da praga do mês de agosto (PINTO, 2014, p.37-38).

Outra versão extraída do trabalho de Pinto (2014), essa contada por Tia Nenem, antiga moradora na comunidade de Acupe, fala da busca incansável por ouro, onde Gonçalves, o senhor de engenho, teria escutado boatos de que havia minas na região, tendo em vista a falta de competitividade e o declínio dos engenhos na época, ele não 
hesitou em procurar. Pedindo autorização à Corte Portuguesa iniciou o deslocamento de escravos para o local, mas falhou em encontrar. Ela relata o aparecimento dessa figura fantasmagórica sobre um cavalo, imponente com fraque preto e cartola vigiando os escravos na noite na sua busca por ouro como fazia quando vivo.

Essas e outras estórias englobam o Nego Fugido, mas afinal o que é o Nego Fugido? Uma manifestação Cultural? Teatro de rua? Há muitas nomenclaturas que procuram definir essa apresentação. Em uma conversa com Monilson dos Santos Pinto", foi possível perceber que também estão presentes os conceitos de "Performance" e do "Teatro" dentro do Nego Fugido.

Segundo os próprios moradores, não há ensaios para a realização do evento, cada personagem sabe exatamente sua ação seguindo o som do atabaque com batidas referentes ao samba de roda do Candomblé, e as letras das músicas mesclam o português com o Yorubá. Uma grande peculiaridade já que as músicas do Candomblé são específicas para serem tocadas em cultos sagrados aos Orixás, mas nesse caso o Nego Fugido se apropria das canções, os instrumentos, analogias musicais, danças e gingados. Ela torna-se profana para narrar uma saga histórica. Os tambores são elemento crucial de abertura de rodas, onde ocorrem as emboscadas. São eles que sinalizam o ritmo e o local onde vai acontecer a roda. A população da cidade que não está participando é pega de surpresa no momento de abertura das rodas, algumas em seus afazeres cotidianos de um domingo, descansando ou lavando roupa, tem um rompimento na rotina monótona quando as personagens interagem com elas.

A origem datada do Nego Fugido é incerta. Mas através de referências da origem dos batuques que existem na manifestação que ditam o ritmo do cortejo, que antecedem o Candomblé; ele vai até os Oriquis, a palavra que vem do lorubá; dividindo-a temos: Ori (cabeça, origem) e Ki (verbo: saudar). Traduzindo literalmente para o nosso vocabulário: Evocação. De acordo com Pinto (2014) e os próprios moradores da comunidade de Acupe são chamadas Aparições. O Nego Fugido é um "Teatro das Aparições". Principalmente por estar lidando com antepassados, descendências que se tornam vividas e presentes durante a apresentação.

Quanto às personagens, os escravos são chamados de negas, são interpretados, na maioria das vezes, por crianças e jovens que pedem dinheiro para poder comprar sua carta de alforria, usando uma calça de algodão branca ou azul, o rosto pintado com óleo e carvão, e na boca utiliza-se a anilina, que avermelhada simboliza o sofrimento. Ficam presos por cordas, mas frequentemente se desprendem, escapando dos caçadores. Os caçadores têm uma customização mais detalhada, chapéu de couro, colete de couro, uma blusa de algodão com botões. Seu rosto é pintado igualmente aos das negas com óleo e carvão, fumam e mascam um charuto com a boca avermelhada também. Usam uma saia de folhas secas de bananeira, preso a ela há cabaças e sinos de ferro, que ressoam alto com os movimentos bruscos e gingas dos caçadores, estes são interpretados por integrantes mais velhos. A saia além de camuflar faz referência a outro relato: os escravos que morriam com os maus tratos e punições eram enterrados 
aos fundos do engenho onde havia uma grande plantação de bananeira, dizem os moradores que as mesmas ao serem cortadas escorriam sangue.

Quem comanda os caçadores é o capitão do mato, ele se difere, pois este é o representante do senhor de engenho, não pinta seu rosto de preto e nem tem sua boca sangrenta, veste um chapéu de couro, calça jeans, bota, um colete de couro também, característico do vaqueiro do nordeste, o único que usava couro, tendo em vista que os escravos de engenhos longe do litoral usavam o couro dos animais que caçavam para fazer vestes; brande diversas vezes seu chicote controlando e ordenando os caçadores para vender e caçar os escravos.

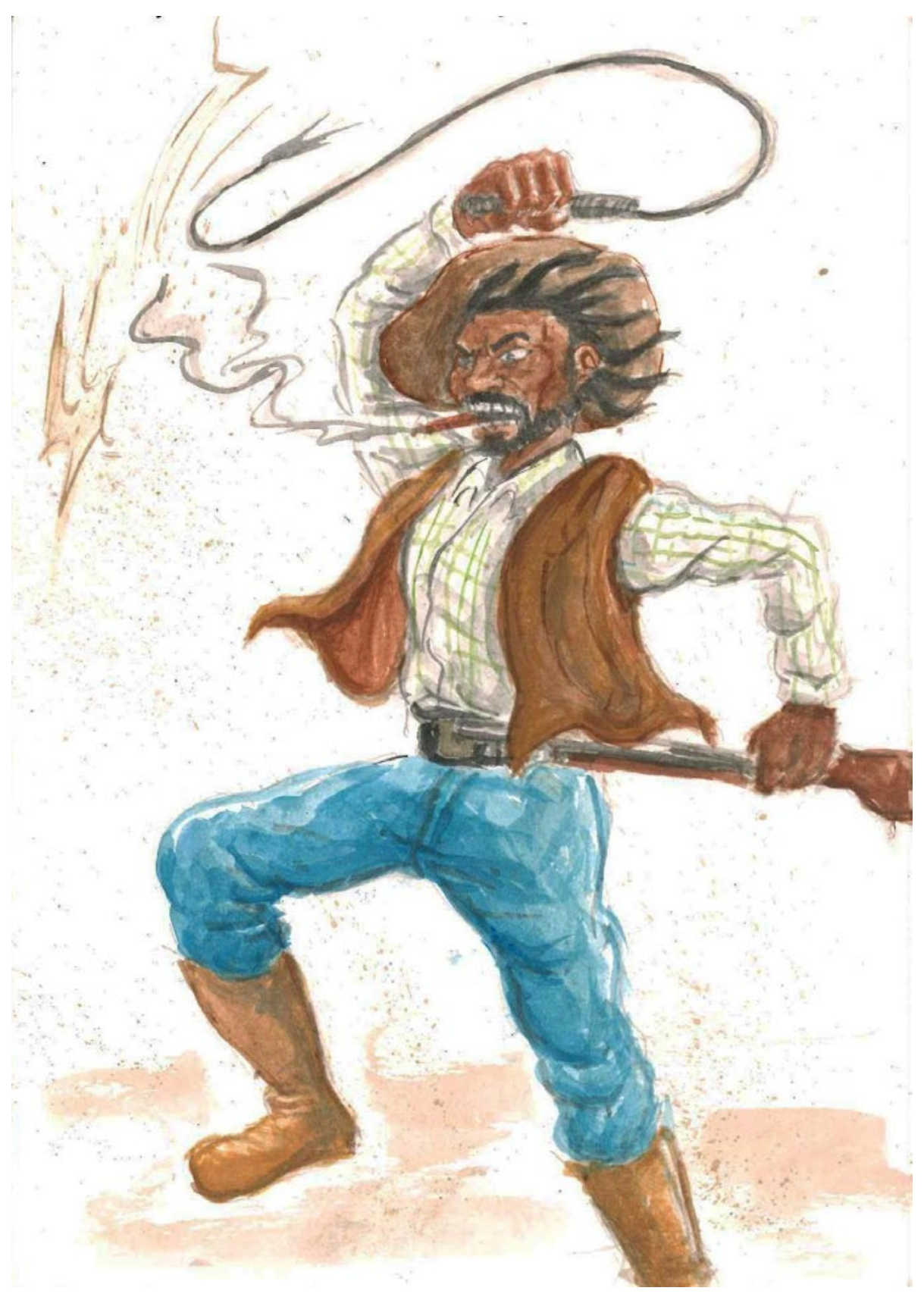

Fig.1, Autor, Capitão do Mato, 2019. Técnica Mista, 148 × 210 mm, acervo pessoal. 
A cada cortejo e parada, forma-se uma roda. Os caçadores caçam as negas, o capitão do mato briga com os capatazes pelos escravos, os militares protegem o rei lutando contra todos, uma maneira cíclica de representar as lutas e revoltas, onde o público acompanha de perto seguindo o elenco pelas ruas do distrito de Acupe. Em toda roda que se abrem as negas se debatem no chão, convulsionam e morrem pelos "disparos" das espingardas dos caçadores, mas uma morte simbólica, onde não se dá como a perda da vida, mas sim da liberdade. O efeito sonoro que causa as "bombinhas" de pólvora simbolizando os disparos, juntamente com o som do atabaque que dita o ritmo das lutas, é chocante à primeira vista de qualquer espectador. O caçador é uma vítima do sistema também, sua boca avermelhada e o rosto pintado assim como as negas, trazem a simbologia do sofrimento, a boca sempre ensanguentada, e o rosto pintado de preto, uma reafirmação da cor preta na pele, ironizando até mesmo o próprio estereótipo que se colocava na época e que se encontra introjetado na sociedade até hoje. Essas duas personagens explicitam uma relação de poder forte, em que ambos podem vir de segmentos diferentes, vindo de África, sendo nascido no Brasil etc. Independente disso estão vivendo em um contexto em que estão sujeitos a caçarem uns aos outros.

É em meio aos conflitos que o caçador percebe que pode vencer o sistema ao qual estava submetido, unindo-se justamente com os escravos que caçava para venda, somente assim ele adquire real autonomia, rompendo com as condições impostas sobre ele e unindo as forças com seus irmãos escravizados.

Outra figura importante é a Dona Santa, chamada de Madrinha, uma alegoria à Princesa Isabel, ela acalma os ânimos dos atores ali presentes durante os conflitos, além de ser uma organizadora do evento extremamente respeitada na comunidade. Sua casa inclusive é onde permanecem todos os materiais referentes ao evento, maquiagem, roupas, instrumentos etc. É o local de reunião para dar início aos preparativos da encenação. Apresenta-se com um vestido e um lenço branco, movimentando-o sempre que necessário para que não haja um acidente, pois em meio a apresentação é notável a efervescência das atuações, por mais que sejam improvisadas parecem convencer-nos de que realmente estão brigando. Atualmente por conta da idade ela já não participa mais, no lugar, um dos integrantes expõe um cartaz fazendo referência à sua pessoa. 


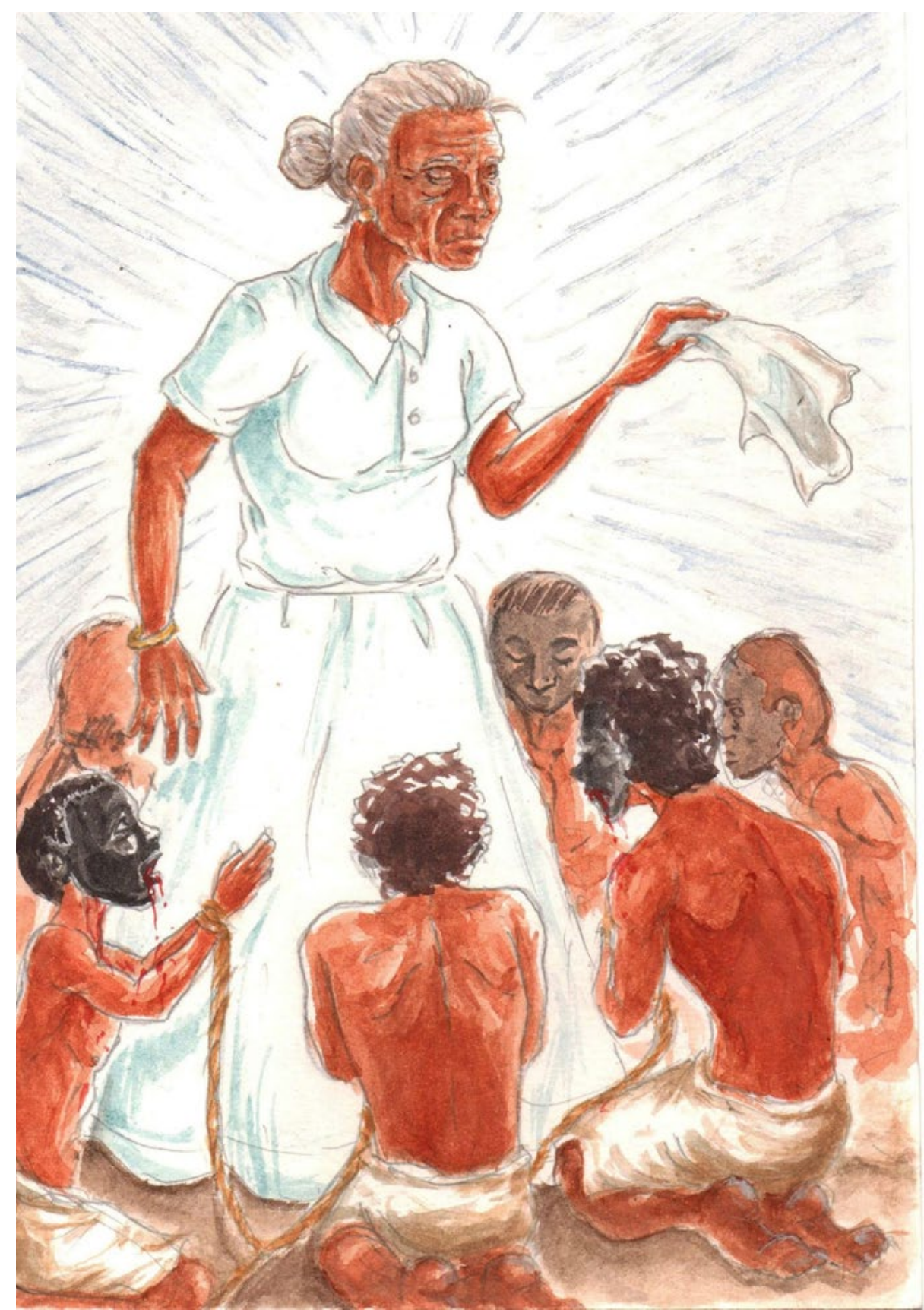

Fig.2, Autor, Dona Santa, 2019. Técnica Mista, 148 × 210 mm, acervo pessoal.

Por fim temos o rei, com seu manto vermelho cercado pelos militares que vestem bota coturno, quepe, usam um cassetete que o protege dos caçadores, que aos poucos vão se rebelando contra o capitão do mato. $O$ rei que detém a carta de alforria gradualmente vai sendo encurralado e quando isso ocorre, uma onda de perseguição e conflitos começa entre os militares e os caçadores. E antes mesmo do embate com os militares, vem primeiramente à queda do capitão do mato, um intermédio entre os senhores de engenho e os caçadores. É incrível a maneira gradual em que as camadas sociais se desmancham perante a opressão maior, a concentração de poder existente e extremamente análoga aos tempos atuais, onde o escravo se rebela contra o caçador, o caçador contra o capitão do mato e assim por diante chegando aos militares e o rei. 


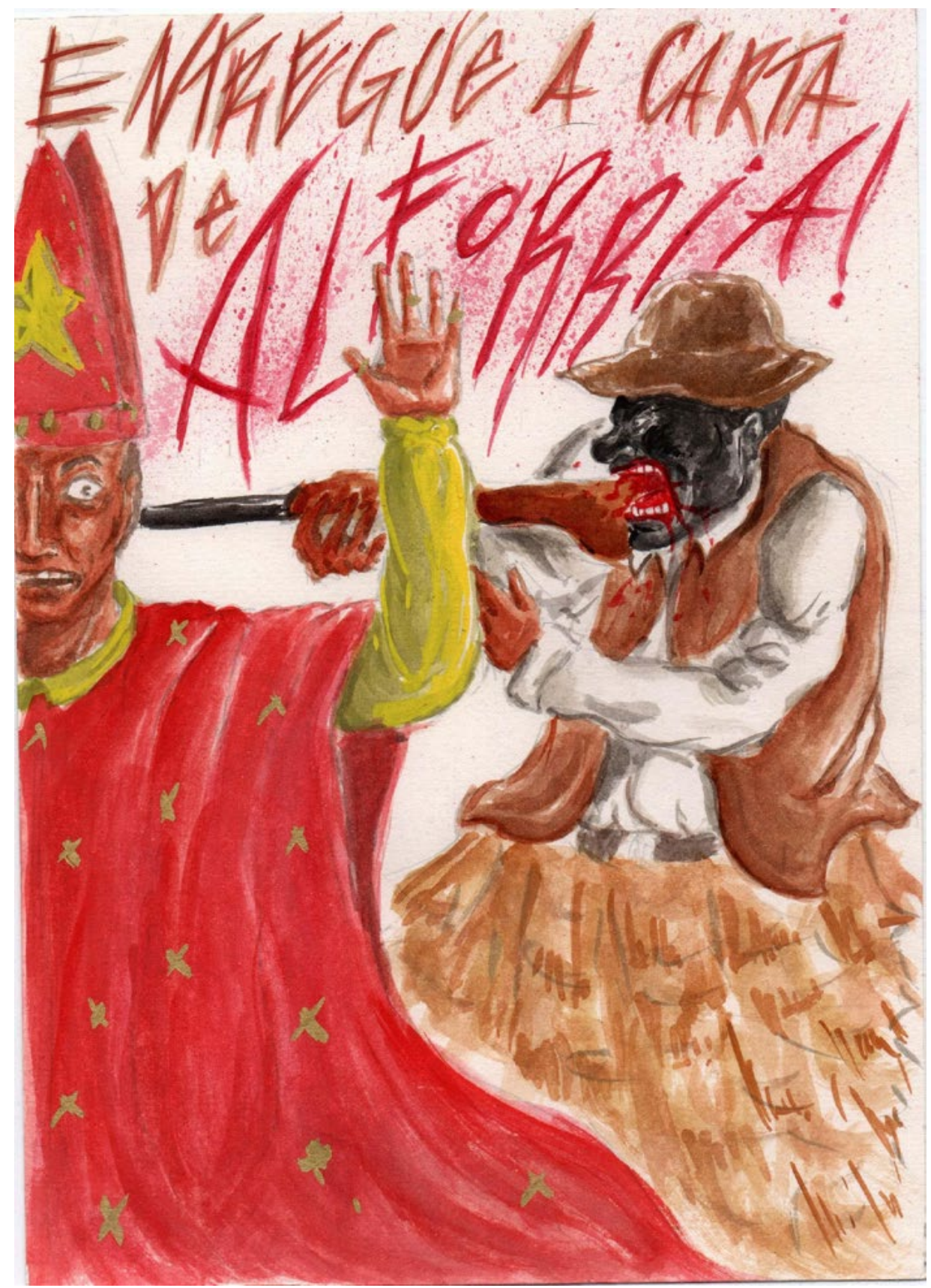

Fig.3, Autor, A Queda do Rei, 2019. Técnica Mista, 148 × 210 mm, acervo pessoal.

A oralidade secular sempre esteve presente, por isso não há ensaios prévios, simultaneamente à vivência e a observação criam uma maneira única de interpretar e reinterpretar o mesmo evento, uma apresentação nunca será igual a outra, o improviso diante das cenas é constante, isso se dá no modo de agir, o gingar, as expressões e interações. A estrutura da narrativa sempre se mantém, configurando-se em todos os domingos do mês. Nos três primeiros é onde as batalhas têm seu início sendo o primeiro ato começando pelo negro em liberdade e festejando, para aí ser capturado e retirado de sua terra natal africana. Há um cortejo quando ocorrem as fugas e capturas seguidas pelas mortes constantes e conflitos entre militares e caçadores. Mas, é no último domingo do mês, no segundo ato, em que ocorre o levante e o rei é finalmente 
capturado, sendo ele uma alegoria ao senhor de engenho (pois, ele não aparece em cena). Adquirida a carta de alforria, ocorre uma peculiaridade, os caçadores passam a ofertar o rei, leiloando-o para quem quiser comprar, a manifestação brinca com os fatos históricos, ironiza-os.

O brincante Monilson Pinto que interpreta o capitão do mato, em depoimento no documentário de Dalila Brito feito Nego Fugido: luta e resistência no Recôncavo da Bahia em 2017, fala o quão reflexiva é a manifestação no momento em que comercializam o rei, propondo não somente uma liberdade dos escravos, mas que de fato haja uma queda do sistema monárquico, em uma das canções das cenas finais coloca-se assim: "Olhaêsibuatã tire a casaca de sibuatã". "Tirar a casaca de Sibuatã" significa tirar o poder do outro, assumir o poder. Mais ainda ao final, no último ato a canção é a seguinte: "lálá me soltou!" (bis). "Nego nagô eu" (bis).

lálá seria a princesa Isabel. Ironicamente os negros agora libertos, depois de passarem todos os domingos do mês propondo um levante revolucionário pela liberdade, agora atribuem essa vitória à lálá, a Princesa Isabel. É uma maneira jocosa de lidar com a história diz Monilson, provocativa, literalmente de brincar com a história. $O$ fato de os caçadores e o capitão do mato serem negros também, caçando seus irmãos por dinheiro, é dito pelo brincante que interpreta um dos caçadores Evilásio Cruz: "É desgraçado caçando miserável" em entrevista concedida pela Arueira Expressões Brasileiras em Maio de 2018 onde ocorreu apresentação do Nego Fugido, no Centro de São Paulo, em frente ao Teatro Municipal a convite do Sesc ${ }^{2}$.

Em uma reportagem feita pela TV Educativa da Bahia entre 1997 e 1998, a historiadora Ana Maria Ramos de Aragão que escreveu sua dissertação de mestrado Nego Fugido, representação da liberdade escrava no recôncavo baiano (1995) defendida na PUC (Pontifícia Universidade Católica) de São Paulo, fala de como os movimentos e danças nos períodos do Quilombo permaneceram na memória da população até os dias atuais, onde o negro escravo saindo para dançar, festejar, namorar, estava naquele momento livre do senhor de engenho. Essa ideia de fugir está atrelada à reconquista dos direitos roubados pela escravidão, onde o negro era privado do lazer. No momento em que ocorre sua captura, ele passa a angariar fundos para comprar sua alforria, tomando consciência de sua condição como propriedade e não mais como homem-livre.

Outro ponto importante é a perda da notoriedade que o capitão do mato tem quando os escravos conseguem a carta de alforria, pois, sendo um representante da repressão, ele passa a ser escorraçado, enxotado pela população negra de maneira jocosa na manifestação. Segundo ela não há registro algum da manifestação em documentos, grande parte de sua pesquisa se deu de maneira oral, conseguindo entrevistar participantes da década de 30 no local. A maneira como se davam as apresentações se difere da infância vivida por ela como moradora da região, e da década de noventa, período de sua pesquisa. Anteriormente mulheres ou meninas não participavam, sendo o grupo composto por homens jovens ou adultos. Atualmente, 
encontram-se faixas etárias diversas, mulheres mais velhas e meninas interpretando tanto as negas quanto os caçadores.

É notável e surpreendente a resistência desse movimento e como perdura atualmente, sua temática nunca deixará de se relacionar com a atualidade, sempre há de se modificar e ressignificar, mas sua essência permanecerá a mesma. A comunidade é constituída de pesqueiros e marisqueiros, sendo este ofício praticamente sua única fonte de renda, há pequenos comércios ao redor, andar pelas ruas, onde poucas são asfaltadas, percebe-se que mal há saneamento básico e casas e barracos improvisados são presentes. Tudo isso em um território que já foi um Quilombo e palco de diversas revoltas só mostra o quão precioso e necessário é o movimento do Nego Fugido, ele engrandece a comunidade, dignifica sua existência. Enaltece a memória do lugar, onde é o único a realizar tais apresentações, uma tradição que dá identidade às pessoas do local, principalmente através de sua secularidade que independe de documentos comprovando sua existência, a maneira como movimenta a população, as expressões chocantes durante e os sorrisos satisfatórios no final do evento, mostram o quão intrínseco o movimento está na vivência dessas pessoas.

\section{Identidade, Tradição e Vigilância}

Stuart Hall em seu livro A Identidade Cultural na Pós-Modernidade trata da identidade cultural no âmbito nacional. O Brasil, assim como outros países na Europa constitui-se em uma diversidade de etnias, definida por Hall da seguinte maneira: "A etnia é o termo que utilizamos para nos referirmos às características culturais - língua, religião, costume, tradições, sentimentos de 'lugar' que são partilhadas por um povo" (HALL, 1992, p.63).

A cultura compartilhada em Acupe pode-se assemelhar a uma "comunidade imaginada", conceito que traz à tona o passado repleto de simbolismos, para que os realizadores e os espectadores diante do ato estejam de fato vivendo e experienciando a memória construída na narrativa. Essas pessoas partilham de uma memória passada através da oralidade. É uma construção que vem sendo feita há quase um século, mesmo com a ausência de registros, a secularidade é explícita. O movimento dá significado à vida das pessoas na comunidade, uma quebra no monótono cotidiano, é um ritual que existe e preexiste mesmo após a morte. O cenário são as próprias ruas do distrito, mesmo sem monumentos especificados, a região historicamente era foco de rebeliões e criação de quilombos. A imagética histórica está atrelada ao povo acupense.

A discussão que Hall traz sobre a "Identidade Nacional" está atrelada à formação do indivíduo no discurso de um país, sua origem e história, dessa maneira se formam instituições, formaliza-se uma única língua, padronizando para os meios educacionais, um sistema de representação que envolve datas e cenários, os mesmos tornam-se comemorativos e ritualísticos, mas isso dentro de uma formação que unifica o ser. A bandeira do Brasil, feriados como a proclamação da república ou a independência 
do Brasil, figuras como Duque de Caxias, figuras repressoras militares e monárquicas tantos elementos que envolvem um sistema repressor histórico não trazem qualquer identificação para população afrodescendente. Deixam espaço para dias no calendário como a consciência negra, um modo de compensar o passado escravocrata para se criar a ideia de nação apaziguando as lutas dos registros.

Essa identidade cultural na pós-modernidade está se fragmentando, as mais diversas questões aparecem, seja de gênero, raça, sexualidade. São cada vez mais tensas as relações nos países, tendo passado pelos mais diversos conflitos migratórios se manterem coesos, há uma divergência de valores que engloba um país, não existe homogeneidade nesse sentido. Sob o processo de globalização, a cultura ocidental toma conta e praticamente monopoliza a cultura de massa, tornando as nações híbridas.

A diversidade de religiões de matriz africana que permeia o país já rompe completamente com essa concepção, basta ver a mistura da língua portuguesa com o Yorubá nas canções do Nego Fugido. Isso por si só já exemplifica o hibridismo de culturas, onde essas canções de cunho sagrado só eram cantadas em cultos, agora, soma-se à língua do colonizador para contar uma história de levante e revolta sobre o sistema repressor que instituiu o idioma hoje falado.

O Brasil cujo processo histórico e migratório é completamente diferente da Inglaterra, tendo em vista que sendo colônia de Portugal sempre houve uma imposição cultural e religiosa; o catolicismo, roupas e costumes portugueses. Pois, a princípio o termo brasileiro estava atrelado ao ofício envolvendo a extração do Pau-Brasil, o povoamento naquela época através das capitanias hereditárias foi o princípio da nacionalidade brasileira, mas ainda assim sempre território de Portugal. Posteriormente, construíram-se os engenhos, a massa de escravos que era trazida com as mais diversas etnias e identidades. Criavam formas de identificação para se relacionarem entre si unindo forças para se rebelarem; como é dito pelo historiador e pesquisador João José Reis:

\footnotetext{
Alguns dos envolvidos na rebelião de 1835 na Bahia, quando interrogados, declararam-se "nagô-ba", "nagô-jabu", nagô-jexá", "nagô-oió", significando que eram naturais dos reinos iorubanos de Egba (ou talvez Yagba), ljebu, llesha, Oyo, ou seja, se adotavam a identidade nagô para relacionar-se com africanos de outras macro regiões, além dos negros, mestiços e brancos da terra, no seio da comunidade nagô cada um sabia que "tinha sua terra", como declarou um deles (REIS, 2007, p.84).
}

Esse trecho exemplifica a disparidade de uma identificação com a identidade brasileira no período, onde os negros tinham plena noção de suas etnias, e de forma a buscarem unir forças adotavam uma identidade que fosse reconhecível para os demais. Povos de regiões diferentes, em outros contextos poderiam até ser rivais ou ter relações conflituosas, mas agora sob as mesmas circunstâncias sociais, cria-se um termo para generalizar essas etnias que se diferem em muitas maneiras culturais. Um modo de se organizar frente ao contexto da escravidão, porém, como já dito, 
jamais perde seu ideal identitário, dentro da mesma identidade nagô existe uma pluralidade de outras identidades, onde cada indivíduo e sua respectiva etnia tinha sua identidade para si, ou como foi dito, "tinha sua terra".

Hobsbawn (1984) ao abordar as tradições inventadas refere-se a costumes ingleses, cerimônias que à primeira vista parecem antigas, mas, que na verdade são recentes se tratando de suas transformações ao longo dos anos, uma maneira de adaptar as gerações mais novas à cerimônias e culturas antigas, relacionar o passado ao presente de maneira que esteja introjetado no cotidiano, um modo de criar a identificação, o sentimento de nação. No livro escrito por Eric Hobsbawn e Terrence Ranger A Invenção das Tradições, logo na introdução, Hobsbawn coloca três classificações acerca das tradições construídas em sociedade:

a) aquelas que estabelecem ou simbolizam a coesão social ou as condições de admissão de um grupo ou de comunidades reais ou artificiais; b) aquelas que estabelecem ou legitimam instituições, status ou relações de autoridade, e c) aquelas cujo propósito principal é a socialização, inculcação de idéias, sistemas de valores e padrões de comportamento (HOBSBAWN, 1984, p.17).

Cabe aqui salientar que a tradição do Nego Fugido dialoga com o tópico a), onde a comunidade desde o século XIX configura e transfigura uma ação afirmativa, que vai de encontro com os valores de um sistema colonial repressor, construindo uma dramatização "inventada" a partir de um conjunto de memórias compartilhadas. Uma abordagem de valores que traz o empoderamento da comunidade em si, um povo que através da ancestralidade marcada pelo sofrimento e luta, coloca-se no lugar do detentor da narrativa, põe à mostra as lutas vividas. $\bigcirc$ tópico b) faz menção às instituições, o que é o caso da Princesa Isabel dita ironicamente como a libertadora dos negros representa a instituição da coroa portuguesa, este fato datado erroneamente nos livros escolares é colocado como ponto de partida da abolição, a manifestação ressalta essas relações de autoridade presentes no período escravocrata. $\bigcirc$ tópico c) traz outra questão referente à socialização e inculcação de ideias, através da escola, da igreja, da TV, do rádio e da internet, uma cultura de massa muitas vezes marcada pelo ocidente, filmes norte-americanos, ou mesmo as novelas que são passadas nos canais televisivos no Brasil, trazem um caráter de embranquecimento, mesmo colocando atores e atrizes negros, acabam esses aparecendo em personagens estereotipados em sociedade (empregada doméstica, bandido), canais religiosos, o evangelismo em alta cumpre esse papel de padronizar comportamentos assim como o desistematizar valores, que censuram e podam as culturas regionais, demonizando-as.

Michel Foucault (2009) em seu livro Vigiar e Punir traz a relação do carrasco no ato de matar um condenado, a exibição de sua força assemelha-se à autoridade do capitão do mato ao caçar um escravo, como é mostrado no trecho a seguir:

O executor não é simplesmente aquele que aplica a lei, mas exibe a força; é o agente de uma violência aplicada à violência do crime, para dominá-la. Desse crime ele é o adversário material e físico. Adversário ora digno de piedade, ora encarniçado (FOUCAULT, 2009, p. 51). 
conceito de vigilância que Foucault traz está atrelado ao condicionamento desde soldados em um batalhão ao de detentos em uma prisão. Transformar o indivíduo em um ser vivendo sob custódia de seus atos, com horários específicos para dormir, comer e realizar tarefas diárias, disciplinar o corpo de maneira coercitiva, mantê-lo sob uma vigia constante, mas através dela utilizar o corpo para fins e meios, quanto maior a utilidade, maior a sujeição e submissão. Gestos e comportamentos que permeiam esse condicionamento estão visíveis na instituição militar, o corpo ereto, a continência etc. O domínio sobre os corpos está atrelado não ao fazer o que se quer, mas da maneira que se quer, impulsionando as capacidades e aptidões de indivíduos dentro da instituição.

A fuga em si já seria um crime passível de punição no período da escravidão, onde o capitão do mato toma a forma do carrasco que pune, representando o sistema repressor do engenho, porém se ele falha em caçar ou punir o escravo, ele torna-se a pessoa a ser punida, da mesma maneira que um carrasco ao falhar em sua execução, convém ele tornar-se a vítima, pois a aplicação da força deve ser direta e precisa caso contrário não haverá impacto sobre o corpo condenado de acordo com o delito, servindo de exemplo para os outros. $O$ capitão do mato não deve matar o escravo, mas caçá-lo e puni-lo, tendo em vista que só pelo fato de haver escapado, ele já falhou em seu dever como autoridade vigilante. Mesmo ele sendo uma autoridade, o mesmo já se encontra submisso a esse sistema, assim como os caçadores são submissos ao capitão do mato, a vigilância dos corpos não necessariamente ocorre dentro de uma instituição fechada, como analisado no contexto de Foucault, mas sob uma sociedade que os repudia, está presente no dia a dia a vigilância desses corpos, os escravos em qualquer equívoco cometido já haveriam de ser punidos; o momento de rebeldia está nos pequenos momentos de lazer usufruído por eles.

De acordo com esses conceitos de identidade, tradição, punição e vigilância o Nego Fugido trata de uma narrativa histórica, pois transfigura os fatos à sua maneira, brinca com eles. Mesmo que em outros estados brasileiros haja estórias que tratam da mesma temática escravocrata, Acupe é único nesse sentido de fazer de maneira dramática, mas ao mesmo tempo jocosa e irônica. As cenas são impactantes, assim como a indumentária, um conjunto de elementos que até hoje criticam o Estado que o negligencia há séculos. Perceber a ausência de saneamento básico em alguns lugares, casas simples e humildes, torna explícito o quão significativo é a manifestação para a comunidade no geral, a reafirmação do seu local de fala, dentro de um espaço de quilombos, em que resiste até hoje ao abandono do governo, ao descaso com a infraestrutura que gere qualidade de vida para a população. 


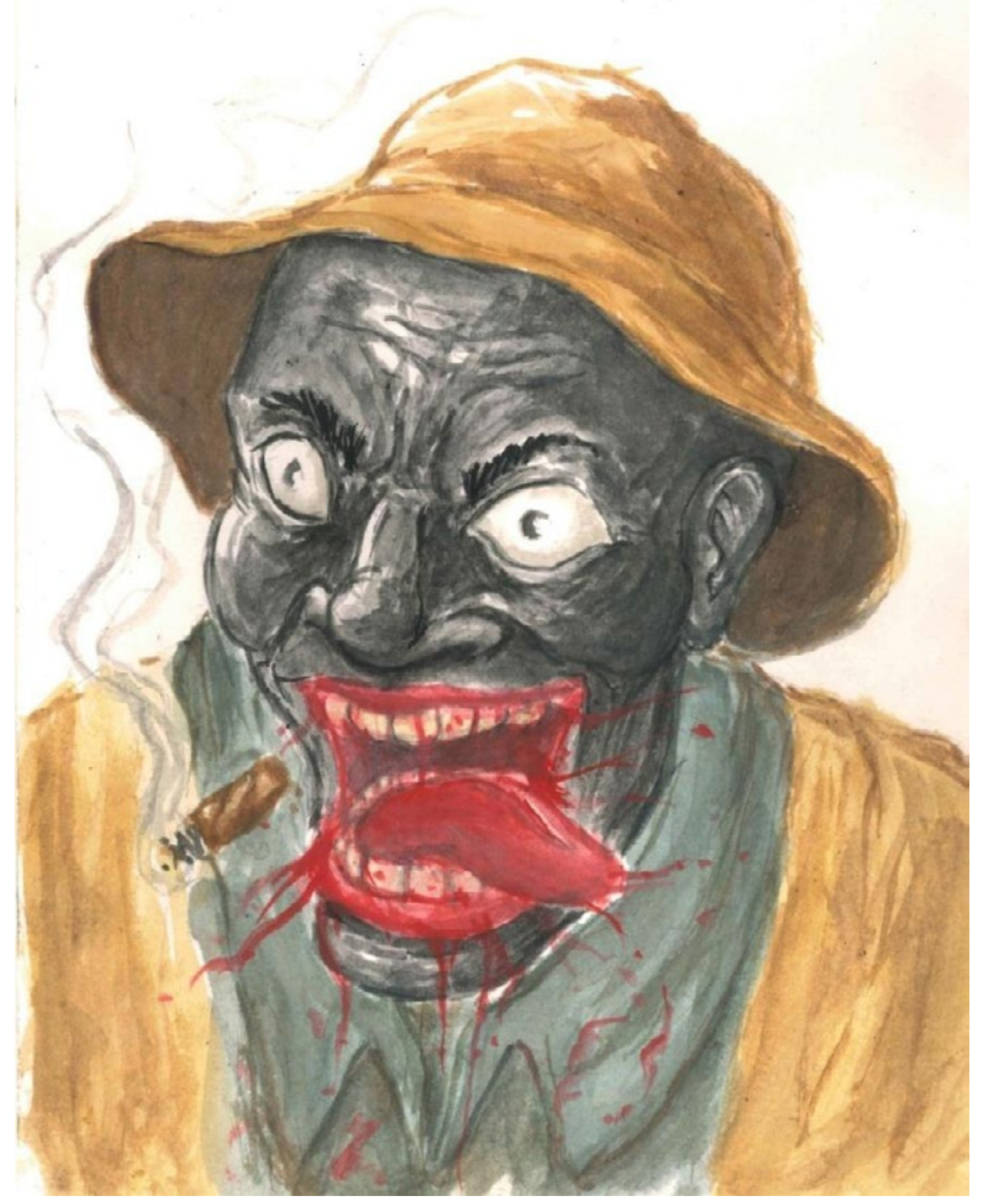

Fig.4, Autor, Caçador, 2019. Técnica Mista, 148 × 210 mm, acervo pessoal.

A apresentação provoca uma inquietação no espectador que surge sempre do campo da dúvida sobre os conteúdos que aprendemos no ensino básico ao longo da vida mesclando-se ao incômodo, quando nos deparamos com tamanha encenação, a ferida colonial recebe uma "cutucada" profunda. Muitas vezes, a repetição do Nego fugido serve para as futuras gerações sempre se lembrarem como de fato se deu a libertação dos negros, o sofrimento vivido pelos antepassados, para nunca ser esquecido e para que jamais se repita. É uma busca contínua pela libertação, pois os mesmos que interpretam sabem das desigualdades, as dificuldades que a comunidade enfrenta quando há baixa nas pescas; e acessando a cultura de massa através da televisão, fica claro que tipo de imagem é veiculada, que representações 
são feitas através das novelas ou comerciais, onde as pessoas majoritariamente são brancas.

Citando Stuart Hall, em uma passagem sobre identidade exemplifica bem a ideia de união que o evento traz:

\begin{abstract}
Assim em vez de falar de identidade como uma coisa acabada, deveríamos falar de identificação, e vê-la como um processo em andamento. A identidade surge não tanto da plenitude da identidade que já está dentro de nós como indivíduos, mas de uma falta de inteireza que é "preenchida" a partir de nosso exterior, pelas formas através das quais nós imaginamos ser vistos pelos outros (HALL, 1992, p.39).
\end{abstract}

Tratando-se da comunidade acupense a maneira como se organizam, exemplifica o trecho acima, é uma ritualística que ocorre todos os anos. $\bigcirc$ processo imaginativo que envolve a criação das personagens, sua atuação, como o negro escravo era visto e tratado pelos caçadores, e como os caçadores eram tratados pelo capitão do mato, negros vindos de diversas regiões do continente africano ou nascidos no Brasil colônia se encontram submissos sob o mesmo sistema repressor que os coloca uns contra os outros. O dinheiro arrecadado para a "compra da alforria", no último domingo do mês é revertido para a compra dos ingredientes para a feijoada, celebrando o então esperado desfecho da libertação pela comunidade.

A experiência vivida e intensificada através dos sentidos, por exemplo, no ver - Nego Fugido dilata o processo criador na representação visceral das cenas, os tambores intensificam as sensações com as cenas. Portanto, a materialização dessas memórias se deu com a necessidade de registrar imageticamente no papel, utilizando as cores e, enfatizando suas expressões que foram molas propulsoras no processo criativo.

\title{
Referências
}

ARUEIRA Expressões Brasileiras. Nego Fugido de Acupe - da Bahia para o Centro de São Paulo, São Paulo, Sesc São Paulo, 2018. Disponível em: https://www.youtube.com/ watch?v=f2S6DiiVqhM. Acesso em 11 de Setembro, 2019.

BRITTO, Dalila. Nego Fugido: luta e resistência no Recôncavo da Bahia. Santo Amaro/BA: UFRB, 2019. Disponível em: https://www.youtube.com/watch?v=ylZoQ8Q_-sU. Acesso em 11 de Setembro, 2019.

DIAS, Belidson; IRWIN, Rita L. Pesquisa Educacional Baseada em Arte: A/r/tografia, Santa Maria, RS, Editora UFSM, 2013.

FOUCALT, Michel. Vigiar e Punir: o nascimento das prisões, Rio de Janeiro: Vozes, 2009. 
HALL, Stuart. A Identidade Cultural na Pós-Modernidade. Tradução Tomaz Tadeu da Silva, Guacira Lopes Louro. 11 ed. Rio de Janeiro: DP\&A, 2011.

HOBSBAWN, Eric; TERRENCE Ranger.et al. A Invenção das Tradições. Tradução de Celina Cardim Cavalcanti. Coleção Pensamento crítico; v. 55. Rio de Janeiro: Paz e terra, 1984.

JESUS, Camila Moreira. Branquitude x Branquidade: uma análise do ser branco, Recôncavo da Bahia, III Encontro Baiano de Estudos em Cultura, 2012.

PINTO, Monilson dos Santos. Nego Fugido: Teatro das Aparições. 2014. Dissertação (Mestrado em Artes Cênicas). Pontifícia Universidade Católica de São Paulo, 2014.

REIS, João José. Presença Negra: Conflitos e Encontros. In: COELHO, Magda Prates (Org.). Brasil: 500 anos de povoamento, IBGE, Centro de Documentação e Disseminação de Informações. Rio de Janeiro: IBGE, 2007, p. 79-100. 